University of Nebraska - Lincoln

DigitalCommons@University of Nebraska - Lincoln

Faculty Publications from the Department of Electrical \& Computer Engineering, Department Electrical and Computer Engineering

2014

\title{
Modeling Molecular Communications at NANO-SCALE with Applications in Medicine and Microbiology
}

Tadeusz A. Wysocki

University of Nebraska-Lincoln, wysocki@uow.edu.au

Follow this and additional works at: https://digitalcommons.unl.edu/electricalengineeringfacpub

Part of the Computer Engineering Commons, and the Electrical and Computer Engineering Commons

Wysocki, Tadeusz A., "Modeling Molecular Communications at NANO-SCALE with Applications in Medicine and Microbiology" (2014). Faculty Publications from the Department of Electrical and Computer Engineering. 315.

https://digitalcommons.unl.edu/electricalengineeringfacpub/315

This Article is brought to you for free and open access by the Electrical \& Computer Engineering, Department of at DigitalCommons@University of Nebraska - Lincoln. It has been accepted for inclusion in Faculty Publications from the Department of Electrical and Computer Engineering by an authorized administrator of DigitalCommons@University of Nebraska - Lincoln. 


\title{
Modeling Molecular Communications at NANO-SCALE with Applications in Medicine and Microbiology
}

\author{
Prof. Tadeusz A Wysocki, PhD, DSc, University of Nebraska-Lincoln, USA
}

Many biological processes that happen at the cellular level can be considered as information transfer, which is the area of telecommunications research. Examples: Gene delivery, targeted drug delivery, viral infections, cell metabolic processes, etc. Developing an accurate but simple simulation model can significantly speedup analysis of those processes and reduce expenses associated with laboratory experiments. It can also help in identifying bottlenecks in signaling pathways and facilitate studying cell responses to changes in underlying conditions (e.g. initial concentrations of proteins, changing reaction speeds, etc.). We propose to use a telecommunications modeling approach based on queuing theory and stochastic modeling to build simulation models tailored to particular biological/medical application. In the presentation, the fundamental aspects of the modelling as well as some of the developed models will be presented and results of simulations compared with the available experimental data.

Tadeusz Antoni Wysocki (IEEE M'94 - SM'98), received the M.Sc.Eng. degree with the highest distinction in telecommunications from the Academy of Technology and Agriculture, Bydgoszcz, Poland, in 1981. In 1984, he received his Ph.D. degree, and in 1990, was awarded a D.Sc. degree (habilitation) in telecommunications from the Warsaw University of Technology.

In 1992, he moved to Perth, Western Australia to work at Edith Cowan University. He spent the whole 1993 at the University of Hagen, Germany, within the framework of Alexander von Humboldt Research Fellowship. In December 1998, he moved to the University of Wollongong, NSW, as an

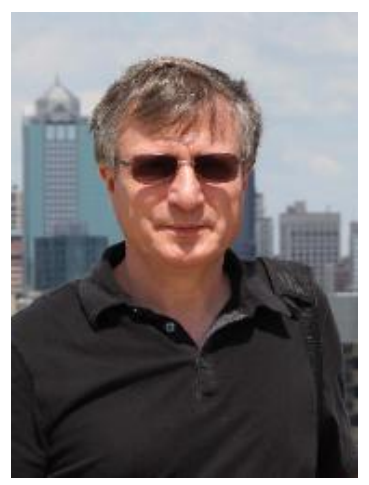
Associate Professor, within the School of Electrical, Computer and Telecommunications Engineering. Since the fall of 2007, he has been with the University of Nebraska - Lincoln as a Professor of Computer and Electronics Engineering at the Peter Kiewit Institute in Omaha, NE. The main areas of his research interests include: space-time signal processing, diversity combining, indoor propagation of microwaves, and molecular communications at nano-scale. He is an author or co-author of over 250 research papers. 